\title{
PERANCANGAN SISTEM INFORMASI PENJUALAN PADA PT DKSH BERBASIS JAVA NETBEANS
}

\author{
Rian Rahmat Ranjani \\ Teknik Informatika, Fakultas Teknik dan Ilmu Komputer, Universitas Indraprasta PGRI Jakarta \\ Jalan Raya Tengah No 80, Kelurahan Gedong, Pasar Rebo, Jakarta Timur \\ rianrahmat112996@gmail.com
}

\begin{abstract}
ABSTRAK
Perkembangan teknologi dan ilmu pengetahuan saat ini dirasakan semakin berkembang dengan pesat, salah satu diantaranya adalah teknologi komputer. Perkembangan teknologi komputer tersebut menuntut adanya kemudahan, kecepatan serta keakuratan dalam mengakses dan mengolah suatu informasi, sehingga penggunaan komputer dapat membantu manusia dalam melaksanakan pekerjaan, terutama untuk menyajikan informasi yang cepat, akurat, tanpa menyita banyak waktu dan tenaga. penulis mencoba merancang suatu sistem informasi yaitu: "Perancangan Sistem Informasi Penjualan Pada Pt Dksh Berbasis Java Netbeans. Berdasarkan latar belakang masalah diatas maka rumusan masalah pada skripsi ini adalah bagaimana merancang Sistem Informasi Penjualan yang bisa memberikan kemudahan kepada pihak PT DKSH meliputi efektivitas, dan efisiensi dalam pendataan transaksi penjualan. Perancangan Sistem adalah suatu proses memahami sistem kemudian merancang sistem informasi yang berbasis komputer, dimana hasilnya nanti adalah berupa sistem komputerisasi. Informasi adalah data yang diolah menjadi kbentuk yang lebih nberguna dan lebih berarti bagi penerimanya. Metode Pengembangan sistem yang di gunakan menggunakan metode prototyping, yaitu peningkatan yang cepat dan percobaan terhadap model kerja (prototyping) dari aplikasi baru melalui proses korelasi dan berulang-ulang yang biasa digunakan ahli sistem informasi dan ahli bisnis. Adapun tujuan : Pengumpulan kebutuhan, membangun prototype / prototyping, evaluasi prototyping, mengkodekan sistem, menguji sistem, evaluasi sistem, dan menggunakan sistem. Manfaat metode prototyping ialah analisa kebutuhan lebih mudah diwujudkan, Mempersingkat waktu pengembangan produk perangkat lunak, dan komunikasi yang baik antara pengembang dan pelanggan.
\end{abstract}

Kata Kunci : Java, Netbeans, Prototyping.

\begin{abstract}
The development of technology and science is currently growing rapidly, one of which is computer technology. The development of computer technology demands convenience, speed and accuracy in accessing and processing information, so that the use of computers can assist humans in carrying out work, especially to present information quickly, accurately, without taking up a lot of time and effort. The author tries to design an information system, namely: "Designing Sales Information Systems At Pt Dksh Java-Based Netbeans. Based on the background of the problem above, the formulation of the problem in this thesis is how to design a Sales Information System that can provide convenience to PT DKSH including effectiveness, and efficiency in data collection of sales transactions. System design is a process of understanding the system and then designing a computer-based information system, where the result will be a computerized system. Information is data that is processed into a form that is more useful and more meaningful to the recipient. The system development method used uses the prototyping method, which is a rapid improvement and experimentation of working models (prototyping) of new applications through a correlation and iterative process commonly used by information systems experts and business experts. The objectives are: Gathering requirements, building prototypes / prototyping, evaluating prototyping, coding the system, testing the system, evaluating the system, and using the system. The benefits of the prototyping method are that requirements analysis is easier to realize, shortens software product development time, and good communication between developers and customers.
\end{abstract}

Key Word: Java, Netbeans, Prototyping.

\section{PENDAHULUAN}

Kemajuan teknologi dan ilmu pengetahuan saat ini dirasakan semakin berkembang dengan pesat, salah satu diantaranya adalah teknologi komputer. Perkembangan teknologi komputer tersebut diharuskan adanya kemudahan, kecepatan serta keakuratan dalam mengakses dan mengolah suatu informasi, sehingga penggunaan komputer dapat membantu user dalam melaksanakan pekerjaan, terutama untuk menyajikan informasi yang cepat, akurat, tanpa menyita banyak waktu dan tenaga. 
PT DKSH merupakan perusahaan induk Swiss yang mengkhususkan diri dalam layanan perluasan pasar, MIS (Management Information System), dan outsourcing. Berfokus di bidang penjualan infrastruktur, PT DKSH menyediakan berbagai macam produk yang dijual. Dalam perkembangannya, saat ini sistem pengelolaan dan penyajian data masih menggunakan aplikasi Microsoft Excel sebagai program aplikasi untuk membantu menyimpan dan menghitung data. Namun penggunaan aplikasi Microsoft Excel tersebut masih memiliki beberapa kelemahan salah satunya adalah proses penyimpanan data yang terbatas sehingga banyak data yang tercampur dan sulit untuk dicari. Sedangkan proses mencari data penjualan dituntut dengan cepat untuk melakukan proses-proses lainnya seperti pembayaran dan pelunasan. Dengan kendala tersebut, perlu ada nya suatu sistem yang mampu terkomputerisasi dalam penyelesaiannya.

Penjualan adalah jumlah yang dibebankan kepada pembeli karena penjualan barang dan jasa baik secara kredit maupun secara tunai. (Warshawsky \& Paul, 1971)

Sistem merupakan suatu kumpulan dari komponen-komponen yang membentuk satu kesatuan (Mahendra, R.G., Sari, M.W., \& Tentua, M. N, 2016). Sistem adalah sekumpulan komponen atau jaringan kerja dari prosedur-prosedur yang saling berkaitan dan saling bekerja sama membentuk suatu jaringan kerja untuk mencapai sasaranatau tujuan tertentu (Sari \& Winni, 2017). Perancangan Sistem adalah suatu proses memahami sistem kemudian merancang sistem informasi yang berbasis komputer, dimana hasilnya nanti adalah berupa sistem komputerisasi (Saifulloh \& Asnawi, 2015). Berdasarkan dari kedua definisi di atas, dari itu penulis dapat simpulkan bahwa sistem adalah sekumpulan elemen-elemen yang saling berinteraksi untuk suatu tujuan tertentu.

Eentity Relationship Diagram (ERD) adalah suatu diagram untuk menggambarkan desain konseptual dari model konseptual suatu basis data relasional. ERD juga merupakan gambaran yang merelasikan antara objek yang satu dengan objek yang lain dari objek di dunia nyata yang sering dikenal dengan hubungan antar entitas. (Wati, 2019)
Berdasarkan latar belakang masalah diatas maka rumusan masalah pada penelitian ini adalah bagaimana merancang aplikasi Penjualan yang bisa memberikan kemudahan kepada pihak PT DKSH meliputi efektivitas, dan efisiensi dalam pendataan transaksi penjualan. Aplikasi ini dapat mempermudah operasi Admin Perusahaan dalam melakukan pengerjaan laporan dan mempercepat dalam proses data pencarian data laporan penjualan PT DKSH.

\section{METODOLOGI PENELITIAN}

Metode penelitian adalah metode yang digunakan untuk mengetahui hasil dari penelitian dengan cara mengumpulkan, mencatat dan menganalisa informasi data yang ada. Penulis menggunakan metode penelitian kualitatif.

Penelitian kualitatif adalah pengumpulan data pada suatu latar alamiah dengan maksud menafsirkan fenomena yang terjadi dimana peneliti adalah sebagai instrumen kunci kesatuan (Onainor, 2019).

Informasi adalah pengolahan data yang diinterprestasikan maupun diklasifikasi yang dipakai dalam proses untu kmengambil keputusan (Tata Sutabri, 2012)

Dan Metode Penelitian Lapangan (Field Research) yaitu mengadakan pengamatan langsung dengan obyek yang diteliti dan melakukan pengumpulan data yang ditemukan langsung di lapangan (Warshawsky \& Paul, 1971)

Penelitian kualitatif adalah penelitian yang bermaksud memahami realita sosial, yaitu melihat dunia yang seharusnya, maka dari itu seorang peneliti kualitatif haruslah orang yang memiliki sifat open minded. Karenanya, melakukan penelitian kualitatif dengan baik dan benar berarti telah memiliki jendela untuk memahami dunia psikologi dan realitas social (Somantri, 2005).

Berdasarkan dari kedua definisi di atas, dari itu penulis dapat simpulkan bahwa Penelitian kualitatif adalah penelitian yang menggunakan cara analisis atau melakukan investigasi karena biasanya peneliti mengumpulkan data dengan cara bertatap 
muka atau berinteraksi langsung dengan orang-orang ditempat penelitian.

Adapun Rancangannya sebagai berikut:

1. Merancang Database

2. Merancang Antarmuka

3. Mengembangkan Antarmuka

4. Melakukan Validasi terhadap Antarmuka

MySql merupakan sebuah perangkat lunak sistem manajemen basis data atau DBMS yang multiuser, dengan sekitar 6 juta instalasi diseluruh dunia. (Tatang, 2019).

XAMPP adalah sebuah software web server apache yang didalamnya sudah tersedia database server MySql dan support php programming, xampp merupakan software yang mudah digunakan gratis dan mendukung instalasi di linux dan windows. (Kurniyawan, 2019).

Netbeans merupakan sebuah aplikasi Integrated Development Environment (IDE) yang berbasiskan Java dari Sun Microsystems yang berjalan di atas swing. (Rerung, 2018)

\section{HASIL DAN PEMBAHASAN}

Analisa Permasalahan

Dari latar belakang yang telah dijelaskan tersebut diatas, penulis mengidentifikasikan masalah dalam penelitian ini sebagai berikut:

1. Sistem pendataan penjualan menggunakan Microsoft Excel 2016, sehingga dalam segi pengolahan data menyita waktu yang relatif lama.

2. Penyimpanan data menggunakan Microsoft Excel 2016, dimana masih memiliki kelemahan yaitu daya tampung record yang kurang maksimal sehingga membatasi data yang di input.

3. Pembuatan laporan administrasi penjualan menggunakan Microsoft Excel 2016, sehingga administrator perlu menginput kembali satu persatu data yang sudah dibuat sebelumnnya.

4. Peroses pendataan maupun pencarian sangat menyita waktu .

\section{Alternatif Penyelesaian Masalah}

Untuk mencari solusi dalam permasalahan yang ada maka penulis membuat suatu sistem yang akan membantu dalam menyelesaikan masalah tersebut. Berdasarkan analisa sistem yang sedang berjalan saat ini penulis melihat adanya kelemahan dan pokok permasalahan pada sistem informasi laporan data kegiatan penjualan PT DKSH, maka penulis memberikan saran penyelesaian masalah diantaranya:

1. Membangun sistem penjualan yang efektif, efisien dan user friendly.

2. Penulisan penelitian ini bertujuan untuk menghasilkan sebuah aplikasi sistem informasi penjualan yang nantinya akan digunakan oleh pihak PT DKSH

3. Membuat aplikasi sistem informasi penjualan menggunakan program java netbeans dan xampp.

4. Penerapan dan uji coba program sistem informasi penjualan untuk membantu mengatasi masalah pada PT DKSH



Gambar 1. Diagram Konteks

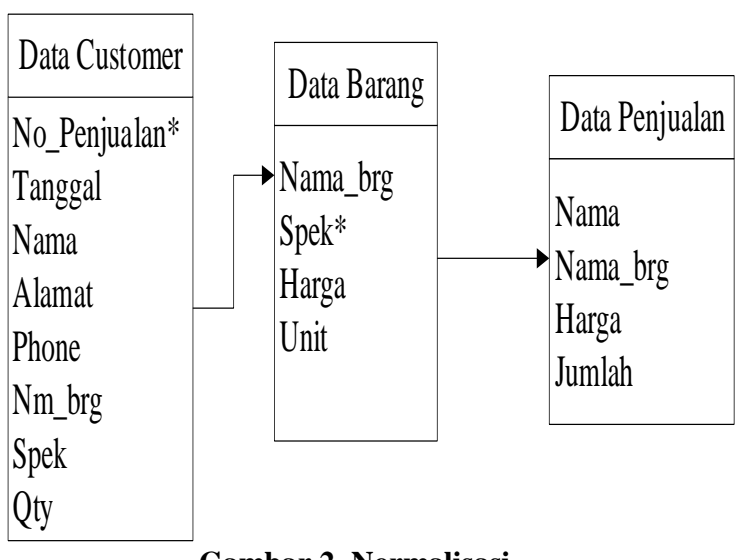

Gambar 2. Normalisasi 


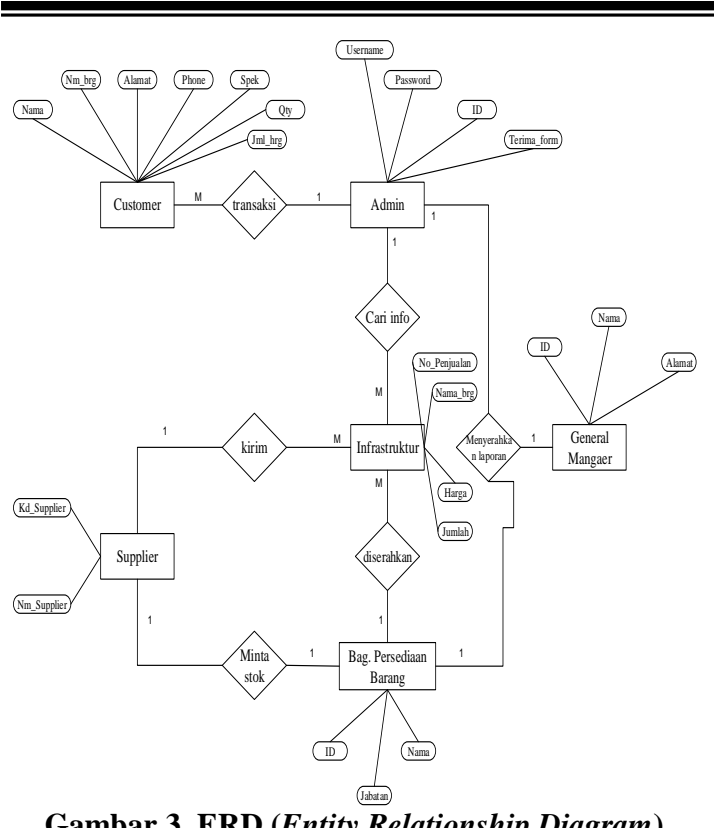

Gambar 3. ERD (Entity Relationship Diagram)

Berikut adalah tampilan dan hasil pengujian pada program yang telah di buat dengan bahasa pemrograman Java.



Gambar 4. Form Menu Utama

Layar di atas tampilan Menu Utama pada Sistem Informasi Penjualan Pada PT DKSH Berbasis Java NetBeans. Pada menu utama tersedia menu bar yang terdiri dari master data yang digunakan untuk memasukkan data yang berkaitan dengan data penjualan, data barang, data garansi barang, dan laporan-laporan.



Gambar 5. Form Data Penjualan
Tampilan ini merupakan input data customer dan pembayaran yang ada dalam sistem penjualan pada PT DKSH

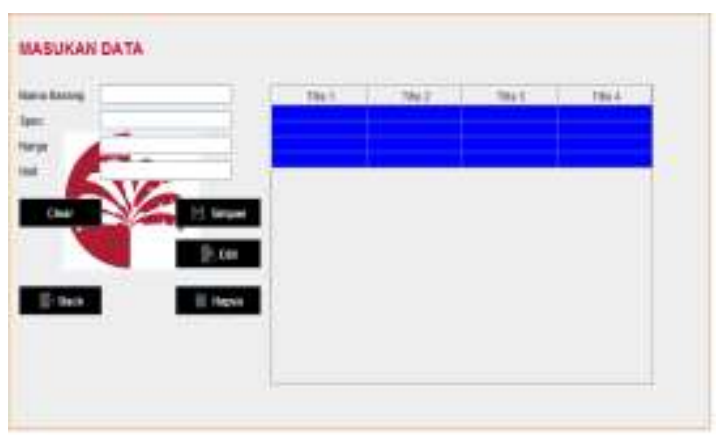

Gambar 6. Form Data Barang

Tampilan ini merupakan tampilan layar data barang yang ada dalam sistem penjualan pada PT.DKSH. Pada tampilan ini merupakan menu detail dari barang yang masuk, keluar dan rekapitulasi barang.

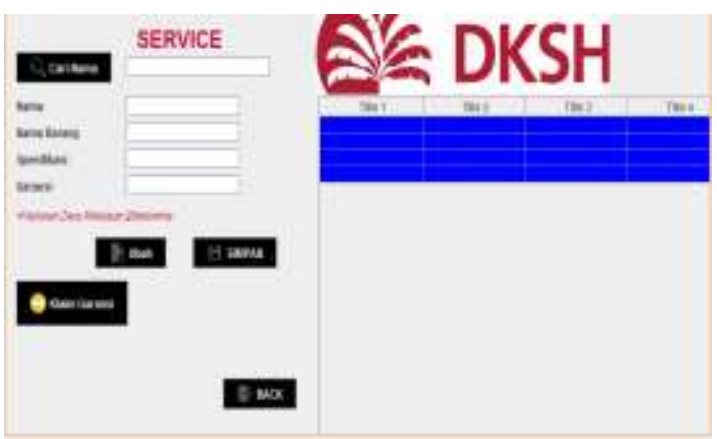

Gambar 7. Data Form Data Garansi Barang

Layar diatas merupakan tampilan layar data service keluar di dalam sistem penjualan pada PT.DKSH. Tampilan ini adalah dimana customer yang memiliki garansi bisa klaim garansi apabila barang yang dibeli terdapat kendala.

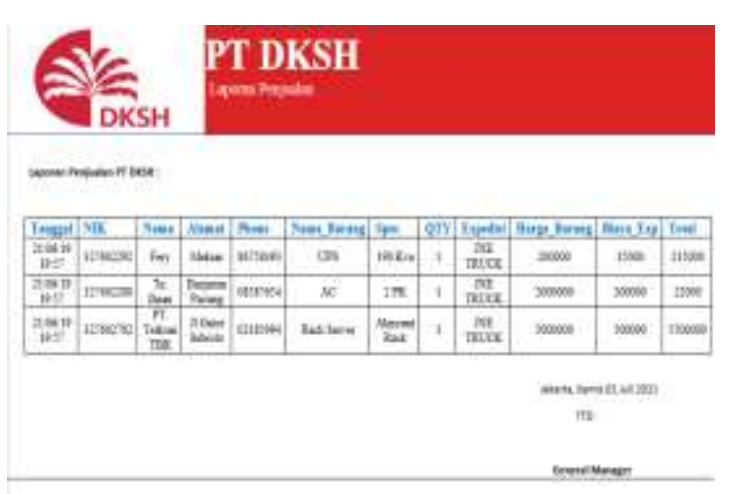

Gambar 8. Laporan Data Penjualan

Layar di atas tampilan form laporan data penjualan. Pada layar form data penjualan 
digunakan untuk mengecek laporan data penjualan.

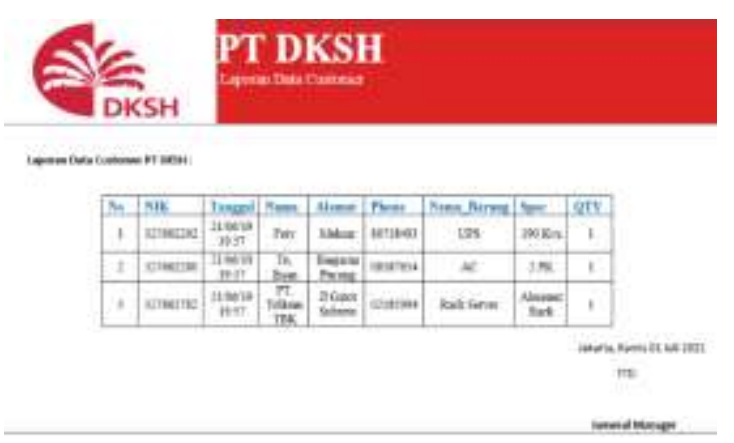

Gambar 9. Laporan Data Customer

Layar di atas tampilan form laporan data customer. Pada layar form data customer digunakan untuk mengecek data customer.

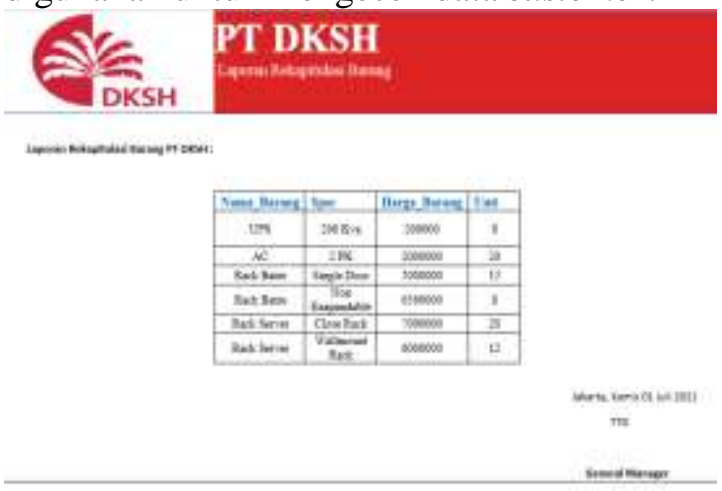

Gambar 10. Laporan Data Rekapitulasi PT DKSH

Layar di atas tampilan form laporan data rekapitulasi barang pada layar form data kegiatan rekapitulasi digunakan untuk mengecek laporan data rekapitulasi barang.



Gambar 11. Laporan Data Garansi PT DKSH

Layar di atas tampilan form laporan data garansi barang pada layar garansi barang digunakan untuk mengecek laporan data garansi barang.

\section{SIMPULAN DAN SARAN}

Sistem Informasi Penjualan yang dapat membantu proses transaksi penjualan yang kompleks secara cepat dan akurat dapat dirancang dengan cara menggunakan tampilan dan fungsi-fungsi yang tepat pada aplikasi sehingga meminimalisir kesalahankesalahan yang biasanya terjadi pada sebuah badan usaha penjualan perseorangan. Beberapa permasalahan yang terjadi pada sistem penjualan seperti kesalahan perhitungan, pencatatan, pengulangan pencatatan transaksi penjualan serta lambatnya pencarian persediaan barang dapat ditangani oleh sistem ini.

Sarannya adalah Fitur yang ada telah dapat mengatasi permasalahan yang ada pada sistem terdahulunya. Namun seiring berjalannya waktu, perkembangan bisnis pada perusahaan juga akan semakin meningkat. Oleh karena itu, diperlukan pengembangan yang lebih lanjut terhadap fitur-fitur yang telah ada.Sistem yang penulis buat tentunya masih banya kekurangan dan masih perlu upaya pengembangan. Maka dari itu harapan penulis agar sistem ini dapat dikembangkan lebih baik lagi.

\section{DAFTAR PUSTAKA}

Kurniyawan, G. (2019). Aplikasi Pengolahan Data Servis Kendaraan Mobil Dan Motor Pada PT. Penerbit Erlangga Cabang Palembang Berbasis Website. Journal of Chemical Information and Modeling, 53(9), 1689-1699.

Mahendra, R.G., Sari, M.W., \& Tentua, M. N, (2016). Simulasi Deteksi Bit Error Menggunakan Metode Hamming Code Berbasis web. Jurnal Dinamika Informatika Volume 5, Nomor 2, September 2016 ISSN 1978-1660. Program Studi Teknik Informatika, Fakultas Teknik Universitas PGRI Yogyakarta.

Onainor, E. R. (2019). Karakteristik Bumil.1(274), 105-112

Rerung, R.R. (2018). Pemrograman Web Dasar. Yogyakarta: Deeppublish.

Saifulloh, \& Asnawi, N. (2015). Data Manajemen Dan Teknologi Informasi. Jurnal Ilmiah DASI, 16(1), 55.

Sari, \& Winni. (2017). Perancangan Sistem Informasi Pembayaran SPP Pada SMA Kemala Bhyangkar Kubu Rayai. 
Journal of Chemical Information and Modeling, 53(9), 1689-1699. http://sir.stikom.edu/1062/5/BAB_II.pd $\mathrm{f}$

Somantri, G. R. (2005). Gumilar Rusliwa Somantri. Makara, Sosial Humaniora, 9(2), 57-65. https://media.neliti.com/media/publicati ons/4388-ID-memahami-metodekualitatif.pdf

Sutabri, Tata. (2012). Analisis Sistem Informasi. Yogyakarta: Andi

Tatang. (2019). Bab Ii Landasan Teori. Journal of Chemical Information and Modeling, 53(9), 1689-1699.

Warshawsky, M., \& Paul, F. W. (1971). the Independent Variable! Simulation, 16(1), 45-46. https://doi.org/10.1177/0037549771016 00108

Wati, R. (2019). No TitleE $\Lambda$ ENH. $A \gamma \alpha \eta, 8(5)$, 55. 